\title{
INFORMATION TECHNOLOGY IN EDUCATION
}

\author{
DOI https://doi.org/10.30525/978-9934-26-043-8-18
}

\section{ВИКОРИСТАННЯ ІНФОРМАЦЙНО-КОМУНІКАЦІЙНИХ ТЕХНОЛОГІЙ У ПРОЦЕСІ ВИКЛАДАННЯ МАТЕМАТИКИ ЗДОБУВАЧАМ ВИЩОЇ ОСВІТИ СПЕЦІАЛЬНОСТІ «014.04 СЕРЕДНЯ ОСВІТА (МАТЕМАТИКА)»}

\author{
Фонарюк О. В. \\ кандидат педагогічних наук, \\ доичент кафедри алгебри та геометрї \\ Житомирський державний університет імені Івана Франка \\ м. Житомир, Украӥна
}

Важливою складовою загальної професійної освіти майбутніх учителів математики $є$ інформаційно-комунікаційні технології (IKT). Вони не тільки сприяють підвищенню інтересу до навчання та поглибленню знань 3 профільних дисциплін, а й допомагають розвиткові у здобувачів вищої освіти навичок самостійно шукати, збирати, обробляти, передавати та використовувати інформацію для вирішення проблем викладання математики в школі - під час роботи за фахом, вже після закінчення університету. Підготовка вчителя математики в університеті має постійно вдосконалюватись, оскільки використання IКТ стало невід’ємною складовою сучасної вищої освіти.

Найбільш значущими завданнями застосування IKT при навчанні майбутнього вчителя математики є:

- індивідуалізація та диференціація навчання;

- вдосконалення контролю i самоконтролю здобувачів вищої освіти;

- сприяння засвоєнню знань, розвитку умінь та навичок як цілісної системи формування професійних компетентностей, що визначає сучасну картину світу;

- удосконалення навичок вирішення педагогічних проблем у майбутній професійній діяльності;

- поліпшення ефективності навчання; 
- покращення якості самостійної роботи здобувачів вищої освіти, майбутніх учителів математики, на основі підвищення мотивації до систематичного навчання;

- оволодіння сучасними технологіями і засобами навчання.

Для виконання цих завдань потрібне неперервне осучаснення організації навчального процесу у вищій школі 3 використанням новітніх педагогічних та методичних матеріалів, включаючи системи для супроводу занять (текстові, мультимедійні, графічні тощо), мережеві та електронні засоби навчання математики, педагогічнометодичні комплекси, відеолекції, мультимедійні курси, системи перевірки знань, електронні книги та енциклопедії, віртуальні інтелектуальні тренажери, ресурси віддаленого доступу тощо.

Враховуючи зазначене вище, на фізико-математичних факультетах університетів впроваджуються нові дидактичні комплекси з вивчення математики, включаючи робочу програму, електронні лекційні матеріали, електронний журнал, систему творчих завдань для самостійного опрацювання, набір тестів для контролю знань та ін.

Здобувачам вищої освіти потрібен доступ до сучасної навчальної інформації 3 математики: спеціалізованих програмних продуктів, серверів 3 розвиненою навігаційною системою, інтернет-ресурсів, освітніх порталів, електронних бібліотек, енциклопедій, довідників тощо.

Також важливим при викладанні математики майбутнім вчителям $\epsilon$ широке використання IKT, що вже надає Інтернет. Зокрема, відкриті web-cервіси, що підтримують обговорення, планування, зберігання файлів, профілі користувачів, списки розсилки та групові взаємодії; онлайн-конференції; послуги, що спрямовані на дотримання здобувачами вищої освіти академічної доброчесності (сервіси 3 антиплагіату Unicheck, StrikePlagiarism та ін.); технології Moodle безкоштовна система керування навчанням, яка спрямована на забезпечення взаємодії між здобувачами вищої освіти та викладачами в процесі навчальної діяльності. Загалом використання вільних вебсервісів та платформ здатне надати вагомі переваги у навчанні математики порівняно з традиційними засобами навчання, а також забезпечити двосторонню комунікацію між викладачем і здобувачем вищої освіти при змішаному навчанні [1, с. 47].

Одним із засобів застосування інформаційно-комунікаційних технологій на заняттях 3 математики на фізико-математичному факультеті $\epsilon$ мультимедіа - корисна освітня технологія, яка характеризується гнучкістю та інтерактивністю, а також здатністю враховувати індивідуальні освітні здібності майбутніх фахівців [2]. Це електронні матеріали для реалізації освітнього процесу, засновані на 74 
мультимедійних технологіях (презентації, відео, анімація, інтерактивні навчальні курси, спеціалізовані комп'ютерні навчальні програми, тренажери, електронні посібники із завданнями), що дають змогу самостійно вивчати математику та окремі їі розділи.

Основні програмні засоби IKT, рекомендовані для освіти майбутніх учителів математики, включають також електронні таблиці, математичні системи, пакети та середовища, електронні навчальнометодичні комплекси $з$ математики.

Із чималої кількості програмних пакетів, що використовуються для розв'язування різноманітних завдань 3 математики, найпоширенішими є Mathematica, Maple, Mathcad, Matlab, Maxima, GeoGebra, Gran, Dynamic Geometry. Спеціалізоване ПЗ для розв'язування математичних задач не тільки покращує реалізацію прикладної спрямованості навчання математики, але й відкриває додаткові можливості для підготовки майбутніх фахівців [3]. За допомогою таких програмних засобів відбувається краще розуміння унікальних здібностей спеціалізованих інструментів для реалізації різних способів та форм отримання кінцевого результату при розв'язуванні завдань 3 математики. Все це актуалізує значення IKT у процесі навчання математики майбутніх вчителів.

Ці пакети здобувачі вищої освіти можуть використовувати при виконанні простих обчислень, розв'язуванні диференціальних рівнянь, комп'ютерного моделювання, статистичних розрахунків тощо. Ряд вбудованих функцій також надає додаткову можливість графічного відображення отриманих результатів. Такі системи також можна використовувати для самоконтролю при розв'язуванні лінійних та нелінійних рівнянь, вивченні функцій та побудові їх графіків, обчисленні похідних функцій, значень функцій у певній точці тощо.

Для перевірки ефективності системи професійної підготовки майбутніх учителів математики слід впроваджувати методи діагностики, які можуть об'єктивно оцінювати рівень знань здобувача вищої освіти. Таке діагностування має здійснюватися за допомогою комп'ютерних тестів, які можна проводити як онлайн, так і в аудиторії, користуючись як існуючими, так i власними розробками 3 використанням сучасних програмних продуктів. Тестування - одна зі складових загальної системи оцінювання знань, умінь та навичок здобувачів вищої освіти, яка використовується для інтегральної оцінки усіх видів їх діяльності та спрямована на якісну освіту майбутнього фахівця. Показники системи оцінки у балах можуть публікуватись на web-сайті фізико-математичного факультету, де здобувачі вищої освіти мають змогу постійно контролювати свій поточний прогрес. 
У цілому використання IKT має значний вплив на зміст, форми і методи підготовки майбутніх учителів математики. Широке використання IKT у навчальному процесі забезпечує його кращу варіативність, прикладну складову та особистісну спрямованість, впровадження інтерактивних компонентів також сприяє завершенню профільного самовизначення та формуванню вмінь та навичок, необхідних для подальшого навчання та професійної діяльності [4].

Проте більшість IKT, що наразі використовуються у закладах вищої освіти, переважно пристосовані лише до одного із типів занять: теоретичного, практичного або контрольного. Сучасним закладам вищої освіти потрібен програмний продукт, який би мав модулі як для викладача, так i для здобувача вищої освіти і при цьому надавав би можливість комп'ютеризувати всі види занять, а також забезпечити ефективний моніторинг успішності майбутніх фахівців.

Таким чином, для успішного навчання майбутніх учителів математики варто якнайширше інтегрувати інформаційнокомунікаційні технології в освітній процес. Але проблема впровадження IKT $є$ багатогранною і має вирішуватись комплексно.

\section{Література:}

1. Рекомендації щодо впровадження змішаного навчання у закладах фахової передвищої та вищої освіти / Міністерство освіти і науки України. URL: https://mon.gov.ua/storage/app/media/vishchaosvita/2020/zmyshene\%20navchanny/ zmishanenavchannia-bookletspreads2.pdf (дата звернення: 1.03.2021).

2. Толмачов В.С., Базиль С.М. Сучасні мультимедійні системи в освітньому процесі. Суми, 2019. $71 \mathrm{c}$.

3. Шроль Т.С. Пакети математичних програм у професійній підготовці майбутніх учителів математики. Рівне, 2017. 282 с.

4. Ткач Ю.М. Сучасні інформаційно-комунікаційні технології у навчанні математичних дисциплін в закладах вищої освіти: монографія. Ніжин, 2016. 358 с. 